\title{
Effect of Arm Sling on Postural Stability in Stroke Patients
}

\author{
EMAN S. FAYEZ, Ph.D.*; RANIA M. TAWIK, Ph.D.*; HATEM SAMIR, M.D.** and \\ MOHAMED A. EL-HOSENY, M.Sc.* \\ The Departments of Physical Therapy for Neuromuscular Disorder \& its Surgery, Faculty of Physical Therapy* and \\ Neurology, Faculty of Medicine ${ }^{* *}$, Cairo University
}

\begin{abstract}
Background: Stroke is the second leading cause of death worldwide, and is the major cause of morbidity, particularly in the middle aged and elderly population. Despite some uncertainty about their efficacy and timing, arm slings are still the most preferred treatment modality for shoulder subluxation in stroke patients.
\end{abstract}

Aim of Study: This study was designed to determine the effect of arm sling on postural stability in stroke patients.

Patients and Method: This study was conducted on fortyfive patients of both sexes ( 30 males and 15 females) with hemi paretic stroke (in the domain of carotid system). Their ages ranged from 45-60 years, the duration of stroke ranged from 6 to 18 months. They were assigned into one group (study group). All patients were assessed on biodex balance device. Data obtained from the study group under two conditions, without arm sling and with arm sling. Data of overall stability index, anteroposterior stability index and mediolateral stability index were statistically analyzed and compared between the two conditions.

Results: The results of the present study revealed that there was a statistically significant improvement in values of overall stability index in arm sling condition compared to without arm sling condition $(p=0.0001)^{*}$. The mean difference between without and with arm sling conditions was 1.16 and the percent of change was $28.85 \%$.

Conclusion: In view of the results of this study, it's possible to conclude that there was a beneficial effect of using arm sling on postural stability in stroke patients and it may play a role in stroke rehabilitation.

Key Words: Stroke -Arm sling - Postural stability-Biodex balance device.

\section{Introduction}

STROKE is a clinical syndrome characterized by rapidly developing clinical symptoms and/or signs. Stroke characterized by loss of cerebral function, with symptoms lasting more than 24 hours or

Correspondence to: Dr. Eman S. Fayez, The Department of Physical Therapy for Neuromuscular Disorder \& its Surgery, Faculty of Physical Therapy, Cairo University leading to death, with no apparent cause other than that of vascular origin [1]. Stroke may result in death of brain tissue due to a lack of oxygen when the blood flow to the brain is impaired by blockage or rupture of an artery to the brain [2]. The two major mechanisms causing brain damage in stroke are, ischemia and hemorrhage. In ischemic stroke, which represents about $80 \%$ of all strokes, decreased or absent circulating blood deprives neurons of necessary substrates. The effects of ischemia are fairly rapid because the brain does not store glucose, the chief energy substrate and is incapable of anaerobic metabolism [3]. Stroke often has profound effects on upper-limb movement capacity and stability. Common complications in the upper extremity after stroke are spasticity and paralysis, which in turn can lead to shoulder subluxation, adhesive capsulitis, impingement syndrome, and rotator cuff injury $[4,5]$. In patients with stroke, balance impairments and decreased ankle proprioception are positively correlated. Abnormal interactions between the three sensory systems involved in balance could be the source of abnormal postural reactions [6]. Balance is the ability to keep the COG within the limits of the BOS, or stability limits; these limits are not fixed, but rather can be modified according to tasks, movements, individual biomechanics, and environmental aspects [7]. Biodex stability platform system was used to investigate individuals' balance performance; this system concentrates on nervous and muscular mechanisms and evaluates muscular nervous control through determination of ability to maintain posture dynamic balance [8]. This study was designed to investigate the effect of arm sling on postural stability in stroke patients.

\section{Patients and Methods}

This study was conducted on forty stroke patients from both sexes ( 30 males, 15 females). The 
patients were selected from the out-patient clinic, Faculty of Physical Therapy, Cairo University in the period from January 2018 to July 2018 . The patients were diagnosed as having stroke based on careful neurological assessment and radiological investigations including Computed Axial Tomography (CT) and/or Magnetic Resonance Imaging (MRI) of the brain. Patients participated after signing a written consent forms approved by the Ethics Committee of the Faculty of Physical Therapy, Cairo University. The patients were assigned into one group (study group).

Inclusion criteria were the patients were diagnosed as having stroke in the domain of carotid system based on careful neurological assessment and radiological investigations including Computed Axial Tomography (CT) and/or Magnetic Resonance Imaging (MRI) of the brain, patients' age ranged from 45-60 years, duration of illness ranged from 6 to 24 months and patients had shoulder subluxation and wear the arm sling.

Exclusion criteria include any problems related to vision, sensation and vestibular systems, deafness or language deficits that may impair patient's cooperation and medically or psychologically unstable patients.

\section{Instrumentations:}

Weight and height scale and Biodex Balance System.

\section{Patient's selections:}

\section{Procedtueres:}

\section{A-Assessment protocol:}

1- Prior to participation in this study, the aim and procedures were explained to the patients and a written consent was obtained from all patients.

2- Detailed history taking and complete neurological examination were done for all patients according to the neurological sheet of Department of Neurology, Kasr Al-Ainy Hospitals. Appendix.

3- Assessment of patient's weight and height using weight and height scale.

\section{4- Assessment of balance:}

- Give the patient full feedback about what we are going to do in this measurement and to be familiar with the device.

- The biodex was setted on dynamic balance then;

1- Enter the patient's age and weight and height to the screen.
2- Detect the platform stability level as we choose level 8 as there are 8 level of difficulty of the platform tilting (which allow from $0^{\circ}$ to $20^{\circ}$ of tilting) where level 8 is the less difficulty.

3- Detect the test by two feet and the test length is $30 \mathrm{sec}$.

4- For the using of Biodex Balance System (BBS) the user is instructed to stand on the center of the BBS platform which is fixed.

5- The patient puts his feet at the most comfortable position before the platform become released. (Still he has a chance to move his feet).

6- Press start to release the platform and ask the patient to move his feet whatever he wants to be balanced to hold the platform by fixing the cursor in the middle of the circle.

7- Once the patient holds the cursor in the middle of the circle, we press NEXT SCREEN and ask the patient NOT to move his feet again and also the platform become fixed.

8- Measure foot parameters as it contain a letter, a number and an angle.

- For the right foot detect the vertical line that passes through the right heel (18), then the horizontal line through the right heel that is completely pressed by the heel (F) and the angle of the second toe of the right foot (25).

- For the left foot do the same. The vertical line (5), the horizontal line (F) and the angle (10).

9- Enter the foot parameters in biodex to start the test.

10- Press NEXT SCREEN to release the platform but without starting the test as I ask to maintain his balance.

11- When the patient was ready the START button was pressed and the test started after 3 second from the pressing.

12- Ask the patient to maintain the cursor in the middle as much as he can for the $30 \mathrm{sec}$. The user is asked to keep that position during the testing period as much as he can. BBS measures Over All Stability Index (OASI), Medial/Lateral Stability Index (MLSI) and Anterior/Posterior Stability Index (APSI) where 0 scoring mean the best posture stability and the largest number indicate bad posture stability.

13-After finishing the 30sec., the platform become fixed again and waits for the comprehensive report. 
After finishing the test without arm sling we begin to test the postural stability with arm sling:

1- Help the patient to wear the arm sling while he was in biodex.

2- With the same foot parameters the patient stands on the platform with his same data (age and weight and height) we choose RE-DO test.

3- With the same parameters of the test (platform stability (8), test duration (30sec) and with both feet.

4- Begin the test as the foot parameters still the same.

5- By pressing NEXT SCREEN the platform becomes released but still the test didn't begin actually.

6- Ask the patient to be ready as he will hear counting 3 after it the test will begin.

7- Ask the patient to maintain the cursor in the middle as much as he can for the $30 \mathrm{sec}$. The user is asked to keep that position during the testing period as much as he can. BBS measures Over All Stability Index (OASI), Medial/Lateral Stability Index (MLSI) and Anterior/Posterior Stability Index (APSI) where 0 scoring mean the best posture stability and the largest number indicate bad posture stability.

8-After finishing the test we get the comprehensive report.

\section{Statistical analysis:}

Descriptive statistics were conducted for expression of the subject characteristics and measured variables of the study group. MANOVA with repeated measures were conducted for comparison of overall stability index, anteroposterior stability index and mediolateral stability index between without arm sling and with arm sling conditions. The level of significance for all statistical tests was set at $p<0.05$. All statistical measures were performed through the Statistical Package for Social Studies (SPSS) Version 19 for windows.

\section{Results}

Forty five patients were enrolled in one group (study group). Data obtained from the study group under two conditions, without arm sling and with arm sling. Data of overall stability index, anteroposterior stability index and mediolateral stability index were statistically analyzed and compared between the two conditions. The mean \pm SD age, weight, height and BMI of the study group were
$56.53 \pm 3.78$ years, $72.37 \pm 12.52 \mathrm{~kg}, 169.31 \pm 7.89 \mathrm{~cm}$ and $25.14 \pm 3.2 \mathrm{~kg} / \mathrm{m}^{2}$ respectively (Table 1 ). MANOVA with repeated measures was conducted to investigate the effect of arm sling on postural stability. There was a significant effect of arm sling on the postural stability $(p=0.0001)$. In overall stability index: The mean \pm SD overall stability index of the study group in without arm sling condition was $4.02 \pm 0.85$ and in with arm sling condition was $2.86 \pm 0.62$. The mean difference between without and with arm sling conditions was 1.16 and the percent of change was $28.85 \%$. There was a significant decrease in the mean values of overall stability index in with arm sling condition compared with that of without arm sling condition $(p=0.0001)$ (Table 2). In anteroposterior stability index: The mean \pm SD anteroposterior stability index of the study group in without arm sling condition was $2.97 \pm 0.68$ and in with arm sling condition was $2.08 \pm 0.41$. The mean difference between without and with arm sling conditions was 0.89 and the percent of change was $29.96 \%$. There was a significant decrease in the mean values of anteroposterior stability index in with arm sling condition compared with that of without arm sling condition ( $p=0.0001)$ (Table 3$)$. In mediolateral stability index: The mean \pm SD mediolateral stability index of the study group in without arm sling condition was $3.24 \pm 0.54$ and in with arm sling condition was $2.37 \pm 0.53$. The mean difference between without and with arm sling conditions was 0.87 and the percent of change was $26.85 \%$. There was a significant decrease in the mean values of mediolateral stability index in with arm sling condition compared with that of without arm sling condition $(p=0.0001)$ (Table 4).

Table (1): Descriptive statistics for the mean age, weight, height and BMI of the study group.

\begin{tabular}{llccc}
\hline & $\mathrm{X} \pm \mathrm{SD}$ & Minimum & Maximum & Range \\
\hline Age (years) & $56.53 \pm 3.78$ & 48 & 60 & 12 \\
Weight $(\mathrm{kg})$ & $72.37 \pm 12.52$ & 56 & 102 & 46 \\
Height $(\mathrm{cm})$ & $169.31 \pm 7.89$ & 152 & 178 & 26 \\
BMI $\left(\mathrm{kg} / \mathrm{m}^{2}\right)$ & $25.14 \pm 3.2$ & 19.16 & 32.24 & 13.08 \\
\hline
\end{tabular}

Table (2): Comparison of overall stability index between without arm sling and with arm sling conditions of the study group.

\begin{tabular}{lcccccc}
\hline & $\begin{array}{c}\text { Overall } \\
\text { stability } \\
\text { index } \\
\mathrm{X} \pm \mathrm{SD}\end{array}$ & $\mathrm{MD}$ & $\begin{array}{c}\text { \% of } \\
\text { change }\end{array}$ & $\begin{array}{c}\mathrm{F}- \\
\text { value }\end{array}$ & $\begin{array}{c}p- \\
\text { value }\end{array}$ & Sig. \\
\hline Without arm sling & $4.02 \pm 0.85$ & 1.16 & 28.85 & 171.16 & 0.0001 & $\mathrm{~S}$ \\
With arm sling & $2.86 \pm 0.62$ & & & & & \\
\hline
\end{tabular}


Table (3): Comparison of anteroposterior stability index between without arm sling and with arm sling conditions of the study group.

\begin{tabular}{lcccccc}
\hline & $\begin{array}{c}\text { Anteroposterior } \\
\text { stability index } \\
\overline{\mathrm{X}} \pm \mathrm{SD}\end{array}$ & $\mathrm{MD}$ & $\begin{array}{c}\% \text { of } \\
\text { change }\end{array}$ & $\begin{array}{c}\mathrm{F}- \\
\text { value }\end{array}$ & $\begin{array}{c}p- \\
\text { value }\end{array}$ & Sig. \\
\hline Without arm sling & $2.97 \pm 0.68$ & 0.89 & 29.96 & 110.13 & 0.0001 & $\mathrm{~S}$ \\
With arm sling & $2.08 \pm 0.41$ & & & & & \\
\hline
\end{tabular}

Table (4): Comparison of mediolateral stability index between without arm sling and with arm sling conditions of the study group.

\begin{tabular}{lcccccc}
\hline & $\begin{array}{c}\text { Mediolateral } \\
\text { stability index } \\
\mathrm{X} \pm \mathrm{SD}\end{array}$ & $\mathrm{MD}$ & $\begin{array}{c}\% \text { of } \\
\text { change }\end{array}$ & $\begin{array}{c}\mathrm{F}- \\
\text { value }\end{array}$ & $\begin{array}{c}p- \\
\text { value }\end{array}$ & Sig. \\
\hline Without arm sling & $\begin{array}{l}3.24 \pm 0.54 \\
2.37 \pm 0.53\end{array}$ & 0.87 & 26.85 & 90.07 & 0.0001 & $\mathrm{~S}$ \\
With arm sling & $2.37 \pm 0$. & & & & \\
\hline
\end{tabular}

\section{Discussion}

Stroke is the second leading cause of death worldwide. It is the major cause of morbidity, particularly in the middle aged and elderly population [9]. Stroke is defined as an acute neurologic dysfunction of vascular origin with sudden (within seconds) or at least rapid (within hours) occurrence of signs and symptoms [10]. The ability to control our body's position in space is fundamental to everything we do. Postural control can be defined as the act of maintaining, achieving or restoring a state of balance during any posture or activity [11] Injury or paralysis of muscles around the shoulder complex may lead to GHJ subluxation. GlenoHumeral Subluxation (GHS), a frequent complication for patients with a poststroke hemiplegia, is reported to be present in 17 to 81 percent of patients with hemiplegia following stroke [6]. Occupational therapy practitioners are encouraged to use evidence-based practice to prevent and manage shoulder subluxation. Current evidence-based interventions for shoulder subluxation include modalities such as electrical stimulation, positioning, and strapping. On the other hand, the use of shoulder sling can be used to decrease stress and the gravitational pull on the glenohumeral joint in order to maintain the anatomical alignment of the shoulder [12]. The results of this study revealed that there was a significant decrease in the mean values of overall stability index in arm sling condition compared to without arm sling condition $(p=0.0001)$. The mean \pm SD overall stability index of the study group in without arm sling condition was $4.02 \pm 0.85$ and in with arm sling condition was $2.86 \pm 0.62$. The mean difference between without and with arm sling conditions was 1.16 and the percent of change was $28.85 \%$. Arm sling could be suggested as a method for treating shoulder subluxation in stroke patients as among various modalities applied to manage shoulder subluxation $[\mathbf{1 3 , 1 4}]$. The results of this study come in agreement with Merve Acar et al., [14] who showed that arm sling application has a beneficial effect on balance in patients with hemiplegia, which may translate to improved balance during activities such as transfers, position changes, retrieving objects from the floor, or reaching forward. The arm sling may be applied for its possible beneficial effect on balance, especially in the early phases of stroke rehabilitation while the upper extremity is still flaccid and arm swing is reduced. Also the result of this study agreed with Gustafsson et al., [15]. Who found that wearing arm sling led to marked improvement in decreasing stress and the gravitational pull on the glenohumeral joint, increasing postural stability in stoke patients, and found that wearing arm sling on shoulder subluxation in stroke patients using radiographs to compare the unaffected shoulder with the affected shoulder as a measure of improvement of the affected shoulder after wearing a shoulder sling. The study by Brooke et al., [16] showed that the arm sling produced the best total asymmetry correction of the shoulder when comparing to subjects with no support. For correcting both vertical and horizontal displacement of the shoulder, indicated that the arm sling was the most effective, also explained that the arm sling was the best at correcting the total displacement of shoulder subluxation. Also, the results of Marvin et al., [17] support the effectiveness and specificity of shoulder support to decrease subluxation after hemiplegia. Güneş et al., [18] said that arm sling improved gait, especially during gait training sessions of patients with hemiplegia who have impaired body image and excessive motion of the COG.

On the other hand the results of this study contradicted with Min Kyun Sohn et al., [19] who evaluated the effect of a shoulder sling on balance in patients with hemiplegia. The results demonstrated that a simple arm sling had no effect on either the static or the dynamic balance tests. Also Louise Bender [20] who searched in hemiplegic shoulder pain found that the arm sling had no effect on shoulder pain.

\section{Conclusion:}

In view of the results of this study, there was a beneficial effect of using arm sling on postural stability in stroke patients and they may play a role in stroke rehabilitation. 


\section{References}

1- World Health Organization (WHO): Health Topics: Stroke, Cerebrovascular Accident, 81 (1): pp. 110-55, 2015.

2- ZIEVE D., JUHN G., DAVID R. and KELLI A. STACY: Stroke; Healthcare Network; ADAM Health illustrated Encyclopedia, 2008.

3- JACK D., BOIAN R. and MERIANS A.S.: Virtual realityenhanced stroke rehabilitation. IEEE Trans. Neural. Sys. Rehabil. Eng., 9 (3): 308-18, 2010.

4- TURNER-STOKES L. and JACKSON D.: Shoulder pain after stroke: A review of the evidence base to inform the development of an integrated care pathway. Clin. Rehabil., 276-98, 2002.

5- ZOROWITZ R., BATES B., CHOI J.Y., GLASBERG J.J., GRAHAM G.D., et al.: Management of adult stroke rehabilitation care: A clinical practice guideline, 2002.

6- CORRIVEAU H., HEBERT R., RAICHE M. and PRINCE F.: Evaluation of postural stability in the elderly with sroke. Arch. Phys. Med. Rehab., 85 (7): 1095-101, 2004.

7- SHUMWAY-COOK A. and WOOLLACOTT M.H.: Motor control: Theory and practical applications, ${ }^{\text {nd }}$ ed. Philadelphia (PA): Lippincott, Williams \& Wilkins, 2001.

8- KIANI P., FARAHPOUR N., KIANI F. and GHASEMI H.: The comparison of semi dynamic balance of young adult and aged men. Reef resources assessment and management technical paper, 40 (2): 87-93, 2014.

9- TSAKANOVA G., ARAKELOVA E., SOGHOYAN A. and AYVAZYAN V.: Oxidative Stress and Post-Ischemic Inflammatory Response in Ischemic Stroke Complicated with Diabetes Mellitus Type 2. Journal of Biosciences and Medicines, 94-8, 2015.

10- PRETORIUS E., WINDBERGER U.B., OBERHOLZER H.M. and AUER R.E.J.: Comparative ultrastructure of fibrin networks of a dog after thrombotic ischaemic stroke. Journal of Veterinary Research, 77 (1), 2010.

11- POLLOCK A.S., DURWALD B.R. and ROWE P.J., J.P.: What is balance? Clinical rehabilitation, 14: 402-6, 2000.

12- VAN OUWENALLER C., LAPLACE P. and CHANTRAINE A.: Painful shoulder in hemiplegia. Arch. Phys. Rehab., pp. 23-6, 2010.

13- FOONGCHOMCHEAY A. and CANNING C.G.: Supportive devices for preventing and treating subluxation of the shoulder after stroke. Stroke, 36 (8): 1818-9, 2005.

14- MERVE ACAR, et al.: The effect of arm sling on balance in patients with hemiplegia, 2010.

15- GUSTAFSSON L. and YATES K.: Are we applying interventions with research evidence therapy for Stroke, Totowa: Humana Press, 44, 2008

16- BROOKE M.M., De LATEUR B.J., DIANA-RIGBY G.C. and QUESTAD K.A.: Shoulder subluxation in hemiplegia: Effects of three different supports. Arch. Phys. Med. Rehabil., 72 (8): 582-6, 2000.

17-MARVIN M. BROOKE: MD'Correspondence information about the author MD Marvin M. Brooke, Barbara J. De Lateur, MD, Gloria C. Diana-Rigby, PT, Kent A. Questad, $\mathrm{PhD}, 2002$.

18- GÜNEȘ YAVUZER, M.D. SÜREYYA and ERGIN, M.D.: Effect of an Arm Sling on Gait Pattern in Patients with Hemiplegia, 2001.

19- MIN KYUN SOHN, M.D., SUNG JU JEE, M.D., PYOUNGSIK HWANG, M.D., YUMI JEON, M.D. and HYUNKEUN LEE, M.D.: The Effects of Shoulder Slings on Balance in patients with hemiplegic stroke, 2004

20- LOUISE BENDER L. and McKENNA K.: Hemiplegic shoulder pain: Defining the problem and its management. Disabil. Rehabil., 23 (16): 698-705, 2001.

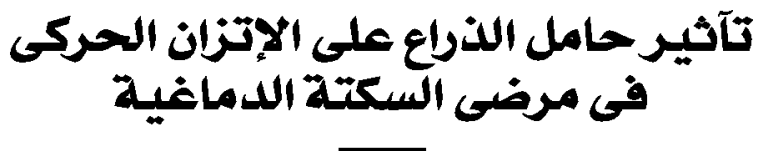

يهدف هذا البحث إلى دراسة تآثير حامل الذراع على الإتزان الحركى فى مرضى السكتة الدماغية.

آجريت هذه الدراسة على خمسة وآريعين مريض من الذين يعانون من السكتة الدماغية فى الشريان السباتى، ويعانفن من خلع فى مفصل

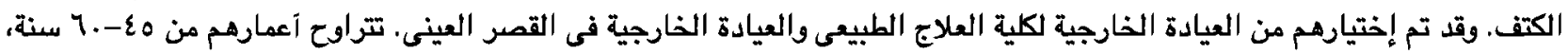

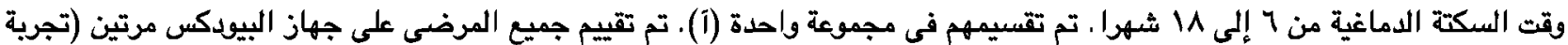

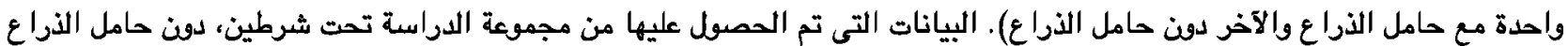

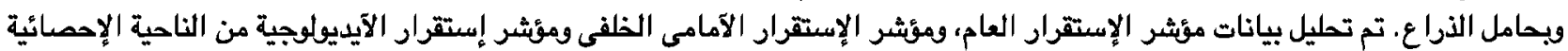
ومقارنة بين الحالتين.

آظهرت نتائج الدراسة الحالية وجود تحسن ذو دلالة إحصائية فى إرتداء حامل الذراع على إستقرار الوضعى فى مرضى السكثة الدماغية. وآخيرا من هذه الدراسة يمكن آن نستنتج آن إرتداء حامل الذراع له تآثير إيجابى على الإتزان الحركى فى مرضى السكتة الدماغية ويمكن

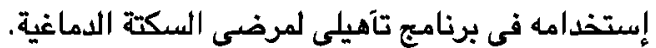

